\title{
Is the Fetal Origins Hypothesis of Diabetes Supported by Animal Research? A Systematic Review and Meta-Analysis of the Evidence
}

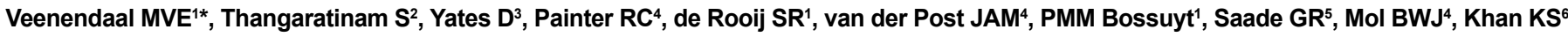
and Roseboom T $\mathrm{J}^{1,4}$

${ }^{1}$ Department of Clinical Epidemiology, Biostatistics and Bioinformatics, Academic Medical Center, University of Amsterdam, Amsterdam, The Netherlands

${ }^{2}$ Department of Obstetrics and Gynaecology and Clinical Epidemiology, University of Birmingham, Birmingham, UK

${ }^{3}$ Library and Information Service, Birmingham Women's NHS Foundation Trust, Birmingham, UK

${ }^{4}$ Department of Obstetrics and Gynaecology, Academic Medical Center, University of Amsterdam, Amsterdam, The Netherlands

${ }^{5}$ Division of Maternal-Fetal Medicine, The University of Texas Medical Branch, Galveston, Texas, USA

${ }^{6}$ Barts and the London School of Medicine, London, UK

\begin{abstract}
The fetal programming hypothesis states that fetal undernutrition during pregnancy results in permanent changes in the offspring's metabolism. A large number of animal studies have evaluated the effect of prenatal undernutrition on later glucose metabolism.
\end{abstract}

Aim: We systematically reviewed the existing animal literature examining effects of prenatal undernutrition on glucose and insulin metabolism.

Methods: An electronic search was performed in Medline and Embase to identify all articles that reported studies investigating the effect of prenatal undernutrition on plasma insulin, plasma glucose and beta cell mass in animal models. Summary estimates of the effect of prenatal undernutrition on mean glucose concentration, insulin level, and beta cell mass were obtained through meta-analysis.

Results: The search resulted in 1827 articles, of which 117 were potentially eligible, based on title and abstract, and 49 met the selection criteria and were included in the review. Prenatal protein restriction (but not general undernutrition) increased plasma glucose concentrations $(0.42 \mathrm{mmol} / \mathrm{l}(95 \% \mathrm{Cl} 0.07$ to 0.77$))$. Both prenatal general undernutrition and protein restriction reduced plasma insulin concentrations (general undernutrition: -0.03 $\mathrm{nmol} / \mathrm{l}(95 \% \mathrm{Cl}-0.04$ to -0.01$)$, protein restricted: $-0.04 \mathrm{nmol} / \mathrm{l}(95 \% \mathrm{Cl}-0.08$ to 0.00$))$ and beta cell mass (general undernutrition: $-1.24 \mathrm{mg}(95 \% \mathrm{Cl}-1.88$ to -0.60$)$, protein restriction: $-0.99 \mathrm{mg}(95 \% \mathrm{Cl}-1.67$ to -0.31$))$. In all cases, heterogeneity was significant.

Conclusions: Despite significant heterogeneity, evidence from experiments in different species suggests that prenatal undernutrition - both general or protein restriction - results in increased glucose and reduced insulin concentrations as well as beta cell mass in later life.

Keywords: Prenatal undernutrition; Fetal programming; Animal studies; Glucose metabolism; Insulin metabolism

\section{Introduction}

In the early 1990s, a cohort study of 64-year-old men in Hertfordshire revealed an inverse association between birth weight and glucose concentrations and insulin resistance [1]. Subjects with the lowest birth weights were 6 times more likely to develop type 2 diabetes or impaired glucose tolerance than those with highest birth weights. These findings led to the 'fetal origins hypothesis', stating that fetal adaptations to reduced nutrient supply predispose to impaired glucose tolerance and type 2 diabetes in adult life [2]. Since, many studies in various populations across the world have investigated the association between birth weight and later risk of type 2 diabetes [3]. A systematic review of human studies on birth weight and type 2 diabetes demonstrated that in most of the middle-aged populations, there was an inverse, graded and independent association between birth weight and risk of type 2 diabetes [3]. Although the inverse association was shown to be the dominant one in most populations, various studies also find a positive association between birth weight and type 2 diabetes risk at the higher end of the birth weight distribution (> $4 \mathrm{~kg}$ ). This would be biologically plausible given the recognized association between gestational diabetes and macrosomia.

Birth weight, however, is only a proxy for maternal undernutrition during gestation and the epidemiological studies in humans are observational, hampering the ability to draw definite conclusions on causality. Animal models allow us to experimentally study the effects of maternal undernutrition during gestation on glucose and insulin metabolism. There is a wealth of animal models used to investigate the developmental origins of type 2 diabetes. Therefore we systematically reviewed the literature on prenatal undernutrition and glucose and insulin metabolism in animal studies and used meta-analysis to obtain summary estimates of the effects of prenatal undernutrition on plasma glucose, insulin and beta cell mass.

*Corresponding author: Marjolein Veenendaal, Department of Clinica Epidemiology, Biostatistics and Bioinformatics, Academic Medical Center, University of Amsterdam, PO box 22660, 1100 DD Amsterdam, The Netherlands, Tel: 3120 5665810; Fax: 3120 6912683; E-mail: m.v.veenendaal@amc.uva.nl

Received August 27, 2013; Accepted November 08, 2013; Published November 14,2013

Citation: Veenendaal MVE, Thangaratinam S, Yates D, Painter RC, de Rooij SR et al. (2013) Is the Fetal Origins Hypothesis of Diabetes Supported by Animal Research? A Systematic Review and Meta-Analysis of the Evidence. J Diabetes Metab 4: 307. doi:10.4172/2155-6156.1000307

Copyright: () 2013 Veenendaal MVE, et al. This is an open-access article distributed under the terms of the Creative Commons Attribution License, which permits unrestricted use, distribution, and reproduction in any medium, provided the original author and source are credited. 


\section{Methods}

\section{Search strategy}

We performed a search in the electronic databases Medline (1951-January 2011) and Embase (1980-January 2011) to identify all articles that reported on fetal undernutrition and plasma insulin, plasma glucose and beta cell mass as diabetes-related outcomes in experimental animal studies. The search terms (MESH and free text) 'undernourished', '(fetal) malnutrition', 'famine', 'starvation', 'caloric restriction', 'protein restriction', 'low protein diet,' 'low calorie diet', 'pregnancy', 'diabetes', 'glucose metabolism', 'glucose', 'insulin metabolism,' 'insulin' and 'beta cell mass' were used. Only articles written in English were included. After screening of titles and abstracts, two reviewers independently examined full text articles and extracted data on study characteristics, quality and results. Reference lists of reviews and relevant papers were hand searched for additional relevant papers.

\section{Study selection}

We included studies that provided data describing outcomes in experimental animal models of prenatal undernutrition that reported on plasma glucose, plasma insulin or beta cell mass as measures of outcome. Prenatal undernutrition included low protein malnutrition and general caloric malnutrition. Studies had to report outcomes in comparison to control animals that were born to a mother that was normally fed throughout pregnancy. Eligibility was evaluated independently by two readers. Disagreements were resolved in consensus discussions.

\section{Data extraction}

Two reviewers independently extracted information on study design, exposure period, animal species and type of undernutrition. To assess methodological quality, data on allocation concealment,

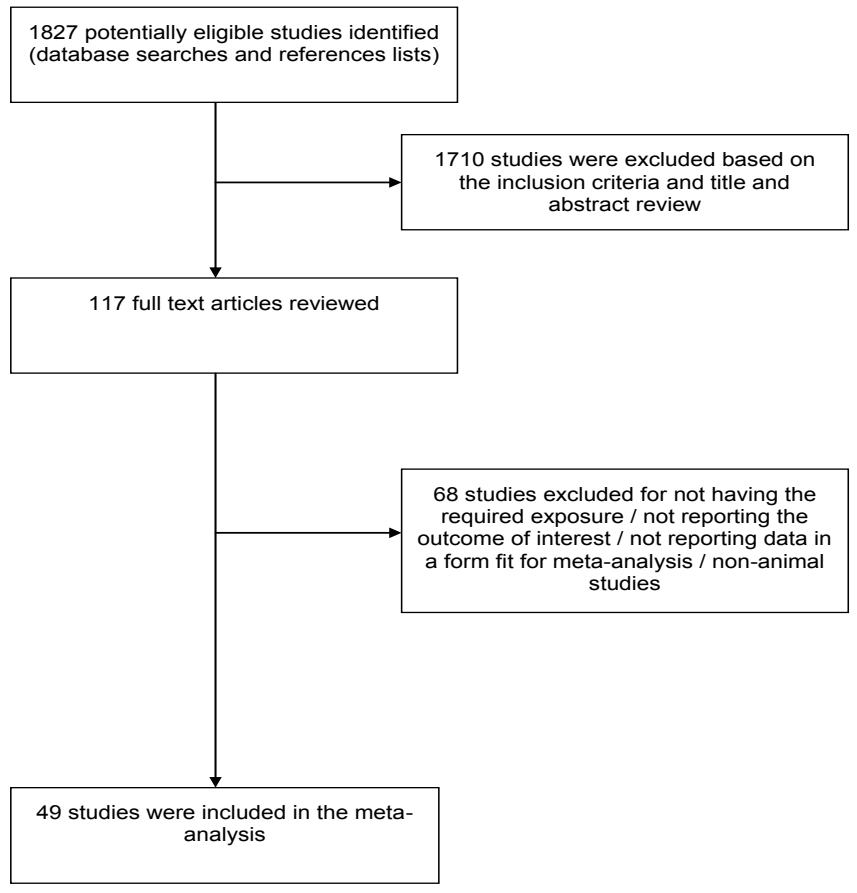

Figure 1: Literature search results for publications reporting on prenatal undernutrition with regard to glucose and insulin metabolism. randomization, blinding and sample size calculation were extracted. When more than two experimental groups were formed, we focused on the experimental group with malnutrition in pregnancy alone. When outcome in offspring was measured at multiple time points, we chose the oldest age at which the measurements were taken. When multiple groups were measured at different ages, both age groups were included. If results were only displayed graphically, outcome was read as precise as possible. Studies that reported results as mean and standard deviation or standard error, and number of animals per group were used for meta-analysis. Data on plasma glucose, plasma insulin and beta cell mass were converted to $\mathrm{mmol} / \mathrm{l}, \mathrm{nmol} / \mathrm{l}$ and $\mathrm{mg}$, respectively.

\section{Statistical analysis}

Data were analyzed using Review Manager Version 5.0. To examine potential publication bias we constructed funnel plots. We examined the possible heterogeneity in results across studies by calculating the $\mathrm{I}^{2}$ statistic.

Summary estimates of the effects of prenatal undernutrition were obtained using a random effects model for meta-analysis, which accounts for both within- and between- study variability. Separate estimates were obtained for model type (protein or general malnutrition) and outcome measure (plasma glucose, plasma insulin and beta cell mass). The summary effects were expressed as mean difference with 95\% confidence intervals (CI). When significant statistical heterogeneity was detected, the sources of heterogeneity were explored and subgroup analyses were performed for different species, sex, experimental regimens or ages at examination. To evaluate the robustness of our results against influential studies, a leaving-one-out sensitivity analysis was performed (in which the analyses were repeated several times, each time leaving one of the studies out to examine that individual studies' influence on the overall outcome).

\section{Results}

The search resulted in 1827 articles, of which 117 were considered potentially eligible after screening titles and abstracts (MV and ST). After reading full text articles (MV and either DY, RP or ST), 49 primary studies met the inclusion criteria and were suitable for data extraction (Figure 1). Twenty-six studies reported on protein restriction, one using a mouse model [4], and twenty-five using a rat model [5-29]. Twenty-four reported on general (caloric) undernutrition, one study using guinea pigs [30] and two on a mouse model [31,32], five using a sheep model [33-37] and 16 studies on rats [7,8,13,38-51] .

\section{Methodological aspects}

Only one study reported blinding of the investigator [34]. Randomization was reported in twenty-four studies, either randomization to the dietary regimen or randomly selecting the pups that were studied from the litters [14,15,17-24,26,28,29,31,32,34$36,39,42,44,48,50,52-54]$. None of the studies reported a sample size calculation or methods for concealment of allocation. Funnel plots of all six outcomes showed symmetrical scattering of the study results around the summary estimate. There was no evidence of a small study effect or publication bias (Supplementary Figure 1).

\section{Plasma glucose after prenatal low protein diet}

Twenty-two primary studies provided data for meta-analysis (464 undernourished animals, 464 controls). Twenty-one studies were performed using rats [7-16,18-21,23-29], one using mice [4]. Using the random effects model we found a higher mean plasma glucose 
Citation: Veenendaal MVE, Thangaratinam S, Yates D, Painter RC, de Rooij SR, et al. (2013) Is the Fetal Origins Hypothesis of Diabetes Supported by Animal Research? A Systematic Review and Meta-Analysis of the Evidence. J Diabetes Metab 4: 307. doi:10.4172/2155-6156.1000307

Page 3 of 8

\begin{tabular}{|c|c|c|c|c|c|c|c|c|c|c|}
\hline \multirow[b]{2}{*}{ Study or Subgroup } & \multicolumn{3}{|c|}{ undernourished } & \multicolumn{3}{|c|}{ Control } & \multirow[b]{2}{*}{ Weight } & \multirow{2}{*}{$\begin{array}{l}\text { Mean Difference } \\
\text { IV, Random, } 95 \% \mathrm{Cl}\end{array}$} & \multirow{2}{*}{\multicolumn{2}{|c|}{$\begin{array}{c}\text { Mean Difference } \\
\text { IV, Random, } 95 \% \mathrm{CI}\end{array}$}} \\
\hline & Mean & SD & Total & Mean & SD & Total & & & & \\
\hline Bertin $1999(7)$ & 6.9 & 0.6 & 9 & 7 & 0.6 & 9 & $4.0 \%$ & $-0.10[-0.65,0.45]$ & & - \\
\hline Bertin 2002 (8) & 2.8 & 1.7 & 40 & 3.9 & 2.1 & 40 & $3.6 \%$ & $-1.10[-1.94,-0.26]$ & & \\
\hline Burdge 2008 (9) & 8.4 & 0.6 & 12 & 6.3 & 1.2 & 12 & $3.7 \%$ & $2.10[1.34,2.86]$ & & \\
\hline Burdge 2008 (9) F & 8.3 & 0.2 & 12 & 6.2 & 0.8 & 12 & $4.1 \%$ & $2.10[1.63,2.57]$ & & \\
\hline Chen 2009 (4) & 9.7 & 2.53 & 10 & 10 & 2.21 & 10 & $1.7 \%$ & $-0.30[-2.38,1.78]$ & & \\
\hline Dahri 1991 (10) & 5 & 1.04 & 12 & 3.8 & 1.16 & 15 & $3.6 \%$ & $1.20[0.37,2.03]$ & & \\
\hline Dahri 1995 (11) & 5.83 & 1.35 & 34 & 5.67 & 1.51 & 29 & $3.8 \%$ & $0.16[-0.55,0.87]$ & & \\
\hline Desai 1997 (12) F & 5.9 & 0.6 & 10 & 5.6 & 0.3 & 10 & $4.2 \%$ & $0.30[-0.12,0.72]$ & & \\
\hline Desai 1997 (12) M & 5.7 & 0.9 & 10 & 5.6 & 0.3 & 10 & $4.0 \%$ & $0.10[-0.49,0.69]$ & & - \\
\hline Dumortier 2007 (13) & 2.75 & 0.58 & 17 & 2.8 & 0.21 & 17 & $4.3 \%$ & $-0.05[-0.34,0.24]$ & & \\
\hline Fernandez-Twinn 2003 (14) & 3.6 & 5.9 & 112 & 3.8 & 3.4 & 104 & $2.8 \%$ & $-0.20[-1.47,1.07]$ & & \\
\hline Fernandez-Twinn 2005 (15) & 6.4 & 0.7 & 12 & 6.1 & 0.8 & 11 & $3.9 \%$ & $0.30[-0.32,0.92]$ & & \\
\hline Gosby $2003(16)$ day 10 & 9.26 & 1.17 & 9 & 9.82 & 1.36 & 8 & $2.9 \%$ & $-0.56[-1.77,0.65]$ & & \\
\hline Gosby 2003 (16) day 26 & 11.04 & 1.39 & 11 & 11.25 & 0.89 & 9 & $3.3 \%$ & $-0.21[-1.22,0.80]$ & & \\
\hline Holness 1996 (18) & 4.1 & 0.9 & 22 & 4 & 0.6 & 33 & $4.2 \%$ & $0.10[-0.33,0.53]$ & & \\
\hline Latorraca 1998 (19) & 4.1 & 1.12 & 14 & 5.5 & 2 & 16 & $3.0 \%$ & $-1.40[-2.54,-0.26]$ & & \\
\hline Latorraca 1998 (19) M & 3.9 & 0.49 & 6 & 4.7 & 1.96 & 6 & $2.3 \%$ & $-0.80[-2.42,0.82]$ & & \\
\hline Martin-Gronert 2008 (20) & 8.5 & 1 & 8 & 5.2 & 0.4 & 8 & $3.7 \%$ & $3.30[2.55,4.05]$ & & \\
\hline Park 2004 (21) & 6.11 & 0.37 & 7 & 6.47 & 0.53 & 7 & $4.1 \%$ & $-0.36[-0.84,0.12]$ & & \\
\hline Petry 2000 (23) day 133 & 4.9 & 0.5 & 16 & 4.8 & 0.4 & 16 & $4.3 \%$ & $0.10[-0.21,0.41]$ & & - \\
\hline Petry 2000 (23) day 63 & 3.6 & 0.5 & 16 & 4.3 & 0.6 & 16 & $4.2 \%$ & $-0.70[-1.08,-0.32]$ & n- & \\
\hline Petry 2001 (24) & 8.4 & 4.1 & 10 & 5.3 & 4.1 & 10 & $0.8 \%$ & $3.10[-0.49,6.69]$ & & \\
\hline Shepherd 1997 (25) & 4.4 & 0.8 & 16 & 4 & 0.4 & 16 & $4.2 \%$ & $0.40[-0.04,0.84]$ & & \\
\hline Sugden $2002(26) \mathrm{F}$ & 5.3 & 0.6 & 8 & 4.1 & 0.6 & 10 & $4.0 \%$ & $1.20[0.64,1.76]$ & & \\
\hline Sugden 2002 (26) M & 4.6 & 0.3 & 8 & 4.2 & 0.6 & 8 & $4.1 \%$ & $0.40[-0.06,0.86]$ & & - \\
\hline Wilson 1997 (27) & 7.3 & 0.3 & 9 & 5.7 & 1.5 & 9 & $3.3 \%$ & $1.60[0.60,2.60]$ & & \\
\hline Zambrano 2005 (28) & 4.2 & 0.73 & 6 & 4 & 0.45 & 5 & $3.8 \%$ & $0.20[-0.50,0.90]$ & & \\
\hline Zambrano 2006 (29) & 6.3 & 0.57 & 8 & 4.7 & 0.57 & 8 & $4.0 \%$ & $1.60[1.04,2.16]$ & & \\
\hline Total (95\% Cl) & & & 464 & & & 464 & $100.0 \%$ & $0.42[0.07,0.77]$ & & \\
\hline $\begin{array}{l}\text { Heterogeneity: } \mathrm{Tau}^{2}=0.71 \\
\text { Test for overall effect: } Z=2 .\end{array}$ & $\begin{array}{l}=253 \\
P=0 .\end{array}$ & s & $=27(P$ & & & $=89 \%$ & & & -1 & 1 \\
\hline
\end{tabular}

Figure 2: Forest plot of mean differences and $95 \% \mathrm{Cls}$ in plasma glucose concentrations (mmol/l) after prenatal low protein undernutrition in all animal studies. Study-specific mean differences were combined by using a random-effects model. SD: Standard Deviation; UN: Undernourished.

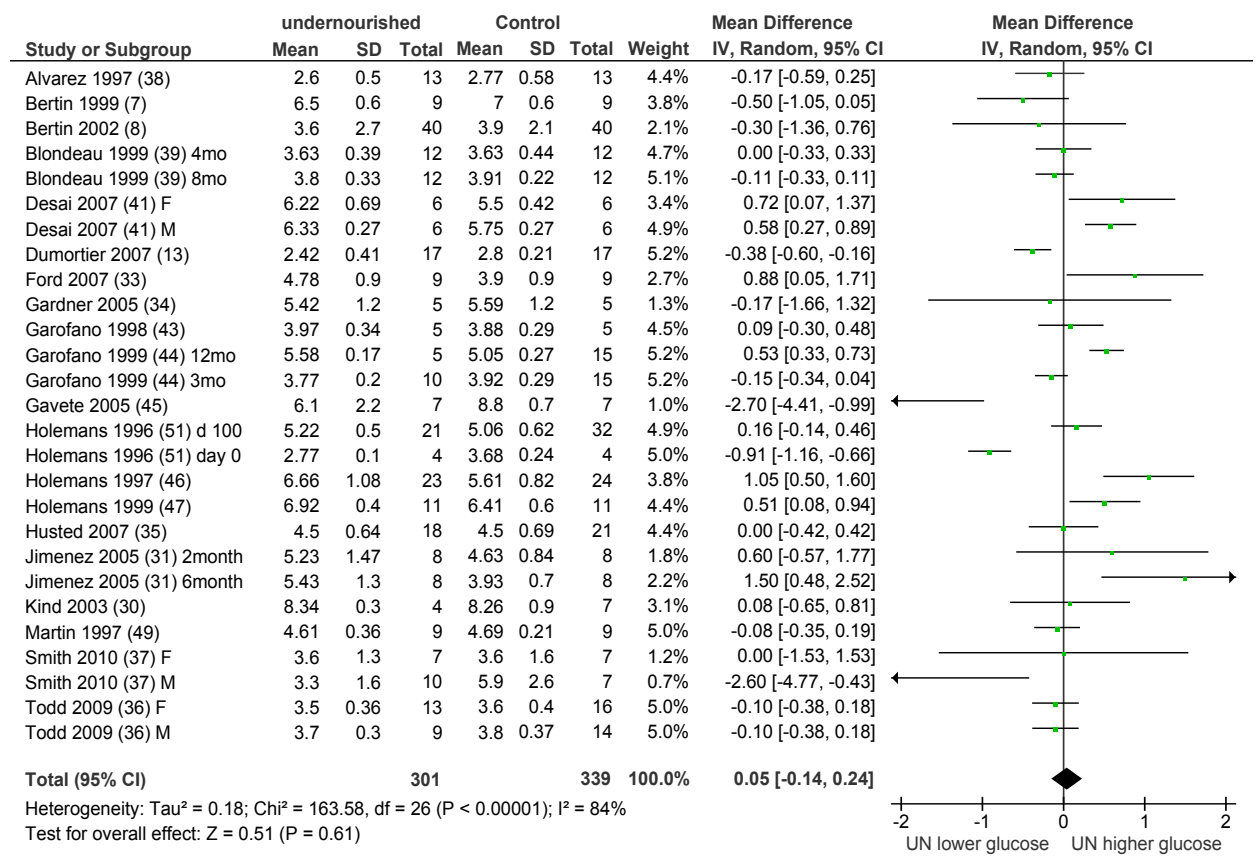

Figure 3: Forest plot of mean differences and $95 \% \mathrm{Cls}$ in plasma glucose concentrations $(\mathrm{mmol} / \mathrm{l})$ after prenatal general undernutrition in all animal studies. Study-specific mean differences were combined by using a random-effects model. SD: Standard Deviation; UN: Undernourished.

level in prenatally undernourished animals compared to the control group: a mean difference of $0.42 \mathrm{mmol} / \mathrm{l}$ (95\% CI 0.07 to 0.77 ) (Figure 2). The results showed statistically significant heterogeneity ( $\left.\mathrm{I}^{2} 89 \%\right)$. The heterogeneity persisted even after separately pooling fasting values, stratifying for the sex of the offspring, or limiting the analysis to Wistar rats only. Offspring of low protein undernourished animals that were older than 6 weeks of age had a $0.54 \mathrm{mmol} / \mathrm{l}$ higher plasma glucose level (95\%CI 0.16 to 0.92$)$ compared to control offspring. But glucose concentrations measured at day 0 were lower in undernourished offspring compared to controls with a mean difference of $-0.62 \mathrm{mmol} / \mathrm{l}$ (95\% CI -1.34 to 0.11 ). In both cases, heterogeneity was substantial, with an $\mathrm{I}^{2}$ of $89 \%$ and $69 \%$ respectively. 
Citation: Veenendaal MVE, Thangaratinam S, Yates D, Painter RC, de Rooij SR, et al. (2013) Is the Fetal Origins Hypothesis of Diabetes Supported by Animal Research? A Systematic Review and Meta-Analysis of the Evidence. J Diabetes Metab 4: 307. doi:10.4172/2155-6156.1000307

Page 4 of 8

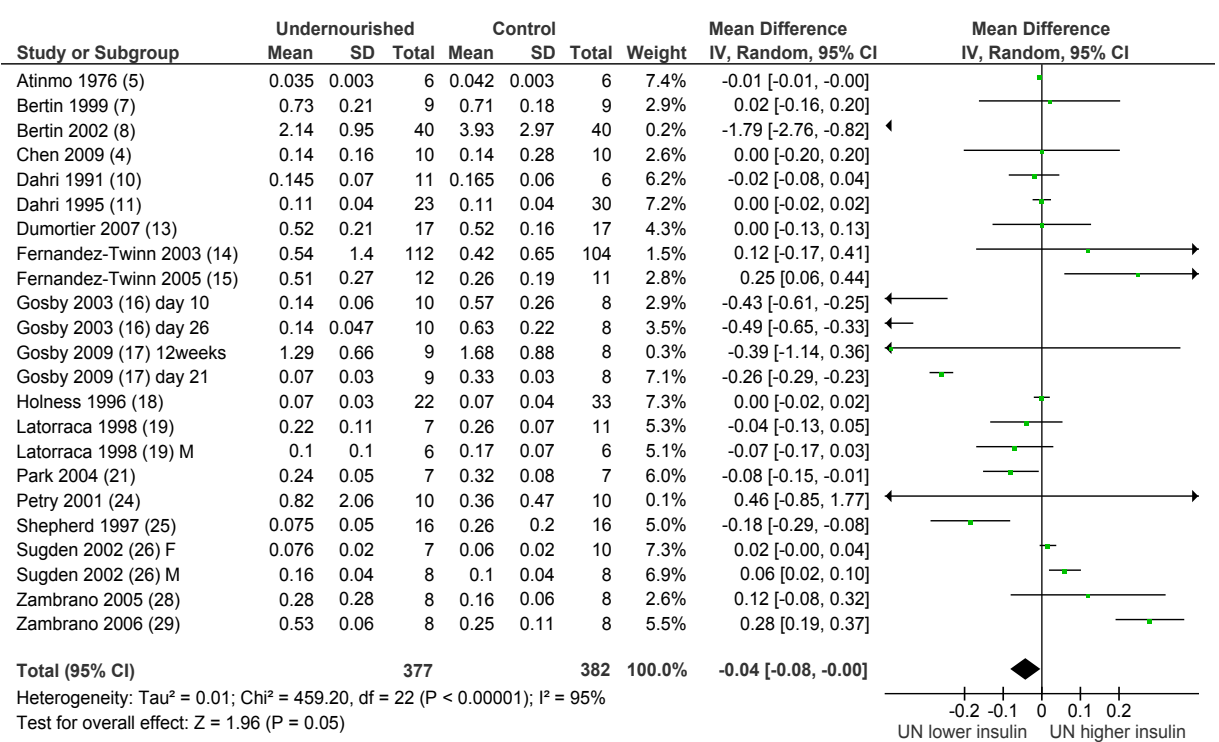

Figure 4: Forest plot of mean differences and $95 \% \mathrm{Cls}$ in plasma insulin concentrations (nmol/l) after prenatal low protein undernutrition in all animal studies. Study-specific mean differences were combined by using a random-effects model. SD: Standard Deviation; UN: Undernourished.

\begin{tabular}{|c|c|c|c|c|c|c|c|c|c|c|}
\hline \multirow{3}{*}{$\begin{array}{l}\text { Study or Subgroup } \\
\text { Alvarez } 1997 \text { (38) }\end{array}$} & \multicolumn{3}{|c|}{ Undernourished } & \multicolumn{3}{|c|}{ Control } & \multicolumn{2}{|r|}{ Mean Difference } & \multirow{2}{*}{\multicolumn{2}{|c|}{$\begin{array}{c}\text { Mean Difference } \\
\text { IV, Random, } 95 \% \mathrm{CI}\end{array}$}} \\
\hline & Mean & SD & Total & Mean & SD & Total & Weight & IV, Random, $95 \% \mathrm{CI}$ & & \\
\hline & 1.21 & 0.32 & 13 & 1.12 & 0.29 & 13 & $0.5 \%$ & $0.09[-0.14,0.32]$ & & \\
\hline Bertin $1999(7)$ & 0.44 & 0.15 & 9 & 0.71 & 0.18 & 9 & $1.2 \%$ & $-0.27[-0.42,-0.12]$ & & \\
\hline Bertin 2002 (8) & 3.75 & 6.13 & 40 & 3.93 & 2.9 & 40 & $0.0 \%$ & $-0.18[-2.28,1.92]$ & & \\
\hline Blondeau 1999 (39) 4mo & 0.37 & 0.12 & 12 & 0.59 & 0.21 & 12 & $1.4 \%$ & $-0.22[-0.36,-0.08]$ & & \\
\hline Blondeau 1999 (39) 8mo & 0.53 & 0.14 & 12 & 0.77 & 0.25 & 12 & $1.1 \%$ & $-0.24[-0.40,-0.08]$ & & \\
\hline Desai $2007(41) \mathrm{F}$ & 0.124 & 0.007 & 6 & 0.096 & 0.005 & 6 & $7.4 \%$ & $0.03[0.02,0.03]$ & & $=$ \\
\hline Desai 2007 (41) M & 0.143 & 0.034 & 6 & 0.107 & 0.022 & 6 & $6.0 \%$ & $0.04[0.00,0.07]$ & & \\
\hline Dumortier 2007 (13) & 0.51 & 0.12 & 17 & 0.52 & 0.16 & 17 & $2.4 \%$ & $-0.01[-0.11,0.09]$ & & \\
\hline Ford 2007 (33) & 0.034 & 0.027 & 9 & 0.013 & 0.036 & 9 & $6.2 \%$ & $0.02[-0.01,0.05]$ & & - \\
\hline Garofano 1998 (43) & 0.41 & 0.09 & 5 & 0.53 & 0.16 & 5 & $1.1 \%$ & $-0.12[-0.28,0.04]$ & & \\
\hline Garofano 1999 (44) 12mo & 0.48 & 0.06 & 5 & 0.38 & 0.14 & 15 & $2.7 \%$ & $0.10[0.01,0.19]$ & & \\
\hline Garofano 1999 (44) 3mo & 0.33 & 0.06 & 10 & 0.51 & 0.16 & 15 & $2.6 \%$ & $-0.18[-0.27,-0.09]$ & & \\
\hline Gavete 2005 (45) & 0.04 & 0.04 & 7 & 0.09 & 0.04 & 7 & $5.3 \%$ & $-0.05[-0.09,-0.01]$ & & \\
\hline Holemans 1996 (51) d 100 & 0.15 & 0.33 & 22 & 0.26 & 0.15 & 25 & $1.2 \%$ & $-0.11[-0.26,0.04]$ & & \\
\hline Holemans $1996(51)$ day 0 & 0.77 & 0.14 & 4 & 1.59 & 0.24 & 4 & $0.4 \%$ & $-0.82[-1.09,-0.55]$ & 1 & \\
\hline Holemans 1997 (46) & 0.14 & 0.05 & 24 & 0.17 & 0.05 & 23 & $6.3 \%$ & $-0.03[-0.06,-0.00]$ & & \\
\hline Holemans 1999 (47) & 0.04 & 0.03 & 11 & 0.1 & 0.03 & 11 & $6.5 \%$ & $-0.06[-0.09,-0.03]$ & - & \\
\hline Husted 2007 (35) & 0.17 & 0.08 & 18 & 0.21 & 0.14 & 21 & $3.5 \%$ & $-0.04[-0.11,0.03]$ & & \\
\hline Ikenasio-Thorpe 2007 (48) & 0.045 & 0.01 & 8 & 0.048 & 0.02 & 8 & $7.1 \%$ & $-0.00[-0.02,0.01]$ & & \\
\hline Jimenez 2005 (31) 2month & 0.122 & 0.1 & 8 & 0.124 & 0.05 & 8 & $3.1 \%$ & $-0.00[-0.08,0.08]$ & & \\
\hline Jimenez 2005 (31) 6month & 0.146 & 0.05 & 8 & 0.343 & 0.39 & 8 & $0.4 \%$ & $-0.20[-0.47,0.08]$ & & \\
\hline Kind $2003(30)$ & 2.46 & 1.62 & 4 & 1.37 & 0.47 & 7 & $0.0 \%$ & $1.09[-0.54,2.72]$ & & \\
\hline Martin 1997 (49) & 0.39 & 0.05 & 9 & 0.35 & 0.09 & 9 & $3.7 \%$ & $0.04[-0.03,0.11]$ & & \\
\hline Oge 2007 (32) 12weeks & 0.08 & 0.05 & 8 & 0.22 & 0.11 & 8 & $2.9 \%$ & $-0.14[-0.22,-0.06]$ & & \\
\hline Oge 2007 (32) 8weeks & 0.06 & 0.03 & 16 & 0.08 & 0.05 & 16 & $6.3 \%$ & $-0.02[-0.05,0.01]$ & & \\
\hline Smith $2010(37) \mathrm{F}$ & 0.58 & 0.29 & 7 & 0.85 & 0.48 & 7 & $0.2 \%$ & $-0.27[-0.69,0.15]$ & & \\
\hline Smith 2010 (37) M & 0.03 & 0.044 & 10 & 0.019 & 0.017 & 7 & $6.2 \%$ & $0.01[-0.02,0.04]$ & & \\
\hline Todd 2009 (36) F & 0.019 & 0.011 & 13 & 0.019 & 0.012 & 16 & $7.3 \%$ & $0.00[-0.01,0.01]$ & & \\
\hline Todd 2009 (36) M & 0.029 & 0.021 & 9 & 0.028 & 0.011 & 14 & $7.1 \%$ & $0.00[-0.01,0.02]$ & & \\
\hline Total $(95 \%$ Cl) & & & 330 & & & 358 & $100.0 \%$ & $-0.03[-0.04,-0.01]$ & & \\
\hline $\begin{array}{l}\text { Heterogeneity: } \operatorname{Tau}^{2}=0.00 \\
\text { Test for overall effect: } Z=2\end{array}$ & $i^{2}=2$ & $\begin{array}{l}3.22, \mathrm{~d} \\
.006)\end{array}$ & & $0<0$ & & & & & $\begin{array}{cc}-0.2 & -0.1 \\
\text { UN lower insulin }\end{array}$ & $\begin{array}{l}0 \\
0 \\
\text { UN highe }\end{array}$ \\
\hline
\end{tabular}

Figure 5: Forest plot of mean differences and $95 \% \mathrm{Cls}$ in plasma insulin concentrations (nmol/l) after prenatal general undernutrition in all animal studies Study-specific mean differences were combined by using a random-effects model. SD: Standard Deviation; UN: Undernourished.

\section{Plasma glucose after prenatal general malnutrition}

Twenty studies provided data on plasma glucose in offspring after prenatal caloric malnutrition. Twelve studies had been performed in rats $[7,8,13,38,39,41,43-47,49,51]$, one in mice [31], one in guinea pigs [30], and 5 in sheep [33-37]. In total, 301 undernourished animals were studied, compared to 339 controls. The mean plasma glucose level was $0.05 \mathrm{mmol} / \mathrm{l}$ higher $(95 \% \mathrm{CI}-0.14$ to 0.24$)$ in undernourished animals compared to controls (Figure 3 ). The meta-analysis showed statistically significant heterogeneity ( $\left.\mathrm{I}^{2} 84 \%\right)$.
Subgroup analysis of rodent models only, stratifying for species, fasting values or sex, did not remove heterogeneity. Undernourished animals measured at day 0 had a significantly lower plasma glucose level, $-0.49(95 \% \mathrm{CI}-0.87$ to -0.11$) \mathrm{mmol} / \mathrm{l}\left(\mathrm{I}^{2} 78 \%\right)$ as opposed to rodents older than 6 weeks, which had a higher plasma glucose level: 0.25 (95\% CI 0.04 to 0.46$) \mathrm{mmol} / \mathrm{l}\left(\mathrm{I}^{2} 79 \%\right)$. Meta-analysis of the effects on sheep only (71 undernourished animals, 79 controls) showed no significant difference in glucose concentrations, with a mean difference of $0.03 \mathrm{mmol} / \mathrm{l}(95 \% \mathrm{CI}-0.31$ to 0.26$)\left(\mathrm{I}^{2} 43 \%\right)$. 
Citation: Veenendaal MVE, Thangaratinam S, Yates D, Painter RC, de Rooij SR, et al. (2013) Is the Fetal Origins Hypothesis of Diabetes Supported by Animal Research? A Systematic Review and Meta-Analysis of the Evidence. J Diabetes Metab 4: 307. doi:10.4172/2155-6156.1000307

Page 5 of 8

\section{Plasma insulin after prenatal low protein}

Data for meta-analysis were available from nineteen experimental studies. One study used a pig model [5], one used a mouse model [4], and the remaining 17 studies were performed in a rat model [7,8,10,11,13-19,21,24-26,28,29]. The meta-analysis, using data from 377 protein restricted animals and 382 controls, showed a lower mean plasma insulin level in undernourished offspring compared to control offspring, with a mean difference of $0.04 \mathrm{nmol} / \mathrm{l}$ (95\% CI -0.08 to 0.00$)$ $\left(\mathrm{I}^{2} 95 \%\right.$ ) (Figure 4 ). The heterogeneity persisted after separately pooling animals according to species, sex or age or separately analyzing fasting values.

\section{Plasma insulin after prenatal general malnutrition}

In the meta-analysis we could include data from 21 studies, obtained in 330 undernourished animals and 358 controls. Fourteen experiments were conducted in rats [7,8,12,13,38,39,43-49,51], 4 in sheep [33,35-37], 2 in mice [31,32] and one in guinea pigs [30]. The mean plasma insulin level was $0.03 \mathrm{nmol} / \mathrm{l}$ lower $(95 \% \mathrm{CI}-0.04$ to -0.01$)$ in the undernourished group compared to control animals, $\mathrm{I}^{2} 86 \%$ (Figure 5). The heterogeneity remained after stratification by fasting values, sex, rodent species or age.

In rats at day 0 , there was no significant effect of prenatal undernutrition on plasma insulin, with a mean difference of $0.23 \mathrm{nmol} / \mathrm{l}$ (95\% CI -0.67 to 0.21 ) ( $\mathrm{I}^{2} 91 \%$ ). However, adult undernourished rats had a lower plasma insulin level than controls, with a mean difference of $0.04 \mathrm{nmol} / \mathrm{l}$ ( $95 \%$ CI -0.07 to -0.01$)$ ( $\left.\mathrm{I}^{2} 91 \%\right)$. The four sheep studies (66 undernourished animals, 74 controls) did not show any difference in the mean fasting plasma insulin level $(0.00 \mathrm{nmol} / \mathrm{l} ; 95 \% \mathrm{CI}-0.01$ to $\left.0.01, I^{2} 4 \%\right)[33,35-37]$.

\section{Beta cell mass after prenatal low protein}

Five rat studies reported beta cell mass of offspring (94 undernourished, 92 control animals) $[6-8,13,22]$. The beta cell mass was lower in the undernourished offspring compared to control offspring, with a mean difference of $-1.24 \mathrm{mg}$ (95\% CI -1.88 to -0.60) (Figure 6). There was statistically significant heterogeneity, $\mathrm{I}^{2} 97 \%$.

\section{Beta cell mass after prenatal general malnutrition}

The 9 studies on rats (91 undernourished and 91 control animals) $[7,8,13,38,40,42-44,49]$ showed a reduction in beta cell mass of 0.44 mg $(95 \%$ CI -0.75 to -0.13$)$ in undernourished animals compared to controls. The results showed statistically significant heterogeneity $\left(\mathrm{I}^{2}\right.$ 94\%) (Figure 7).

\section{Sensitivity analysis}

In a series of sensitivity analysis, we evaluated the robustness of our findings by repeating the analyses a number of times, each time leaving one study out of the meta-analysis. If a study appears to be an outlier, with results very different from the rest of the studies, then its influence will become apparent, as the result without the study would be very much different from the result of the meta-analysis of all the studies. All sensitivity analyses, for each of the six outcome measures evaluated, confirmed the stability of our analysis. No influential individual study could be identified.

\section{Discussion}

Although heterogeneity in all meta-analyses was significant, the results generally support the fetal origins hypothesis and show that both general and low protein undernutrition during gestation results

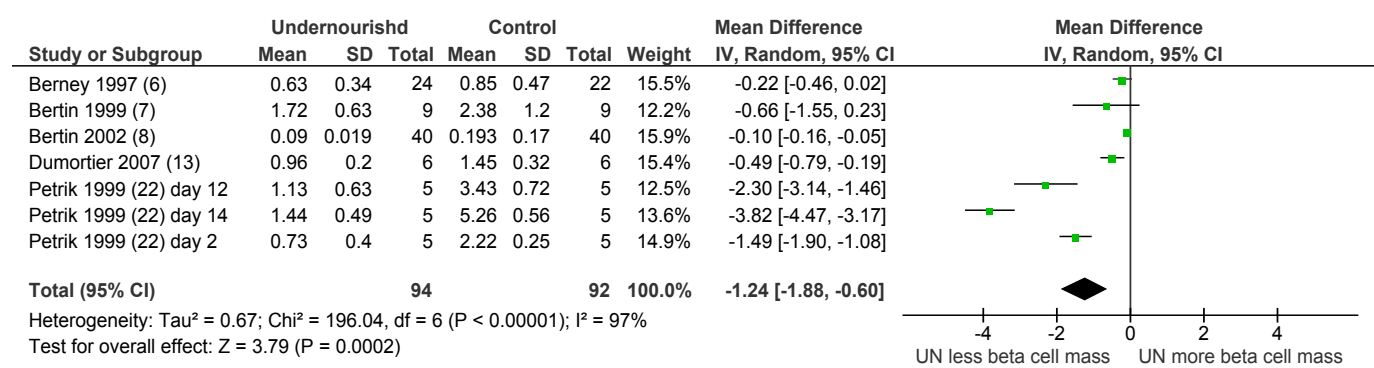

Figure 6: Forest plot of mean differences and 95\% Cls in beta cell mass (mg) after prenatal low protein undernutrition in all animal studies. Study-specific mean differences were combined by using a random-effects model. SD: Standard Deviation; UN: Undernourished.

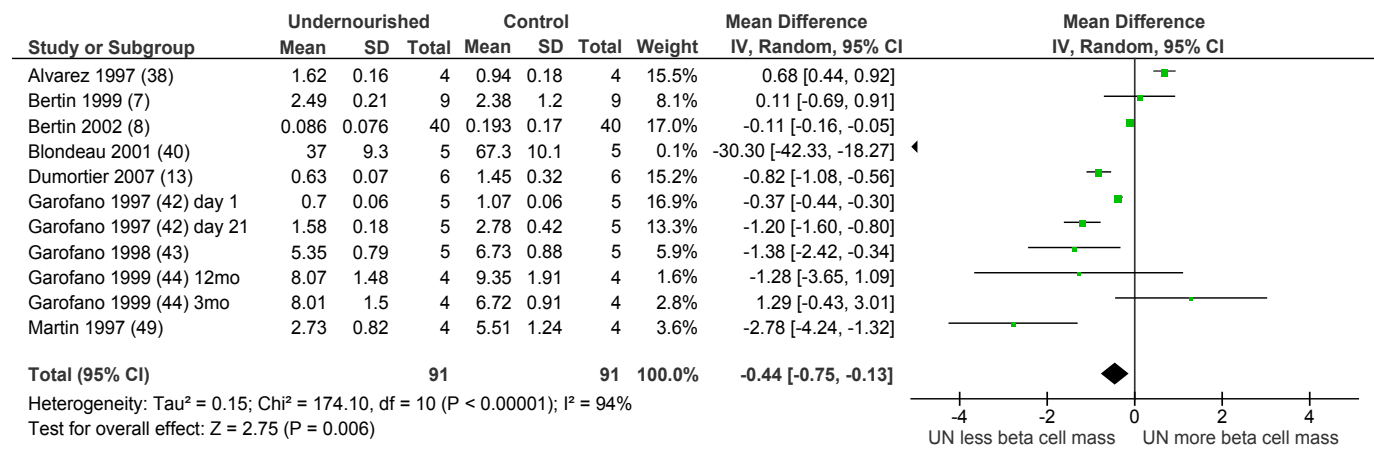

Figure 7: Forest plot of mean differences and $95 \% \mathrm{Cls}$ in beta cell mass (mg) after prenatal general undernutrition in all animal studies. Study-specific mean differences were combined by using a random-effects model. SD: Standard Deviation; UN: Undernourished. 
Citation: Veenendaal MVE, Thangaratinam S, Yates D, Painter RC, de Rooij SR, et al. (2013) Is the Fetal Origins Hypothesis of Diabetes Supported by Animal Research? A Systematic Review and Meta-Analysis of the Evidence. J Diabetes Metab 4: 307. doi:10.4172/2155-6156.1000307

Page 6 of 8

in increased glucose and reduced insulin concentrations and beta cell mass in the offspring.

Meta-analyses of animal studies are known to show significant heterogeneity [55]. Our findings are in line with this, and we have to be cautious when interpreting the results. There are various sources that could have contributed to the heterogeneity, including the animal mode, species, type of glucose/insulin assay used, quantification method used for assessment of beta cell mass and variations in sample collection and storage, standards and quality control samples and matrix effects will all have contributed to the heterogeneity observed in our meta analyses. We have only been able to explore a few potential sources of heterogeneity, including species, age of the animals at investigation and protocol (fasted or not), and these factors only accounted for a small part of the heterogeneity.

Methodological heterogeneity was one of the major reasons for the heterogeneity observed. The methodological quality of most reported studies was suboptimal, with only one study reporting blinding of the investigators [34], and less than half of the included studies reporting randomization of the animals. None of the studies reported a sample size calculation. In contrast to human studies, randomization, blinding, sample size calculation and planned analysis were not standard. Animal studies that did not report randomization and blinding have been shown to be more likely to report a difference in study groups than studies that did use these methods [55].

The findings from animal research in this review are in line with evidence from human studies, although for ethical reasons obviously these studies cannot be carried out experimentally in humans and therefore are observational in nature. A prospective cohort study in India showed significantly lower cord blood insulin concentrations in babies born from malnourished mothers, compared to controls. In that study malnourishment was defined as a BMI of less than $17 \mathrm{~kg} /$ $\mathrm{m}^{2}$ [56]. In subjects prenatally exposed to the Leningrad siege between 1941 and 1944, there was no difference in concentrations of fasting and 2 hour plasma glucose during an oral glucose tolerance test compared to unexposed subjects. In utero exposed subjects also did not have different plasma insulin concentrations or an excess of known diabetes or glucose intolerance [57].

Three studies have reported on the long term effects of prenatal exposure to the Dutch famine of 1944-45 [58-60]. Glucose tolerance was decreased in subjects that were prenatally exposed to famine when measured at both age 50 and 58 years [58,59]. In a subset of participants, an intravenous glucose tolerance test was performed. The results showed impaired glucose tolerance in prenatally exposed subjects, especially those exposed in mid and early gestation. This effect was suggested to be caused by an insulin secretion defect [60]. Similarly, in adult men and women prenatally exposed to the Chinese famine (1959-1961) there was an increased prevalence of hyperglycemia defined as increased fasting plasma glucose, impaired glucose tolerance or a previous diagnosis of type 2 diabetes [61].

In a recent systematic review of the evidence from animal experiments studying the effects of prenatal undernutrition on later hypertension risk, we found similar results. In general, the results supported the fetal origins hypothesis, fetal undernutrition increased blood pressure levels in the offspring. But here too, heterogeneity was considerable.

In summary, this systematic review shows that the results from animal experiments support the fetal origins hypothesis: prenatal undernutrition leads to a disturbed glucose and insulin metabolism and a decrease in beta cell mass in later life.

\section{Acknowledgement}

The present study was supported by the Netherlands Heart Foundation (grant number 2007B083). The funder played no role in the report of the review.

\section{Contribution Statement}

The authors' responsibilities were as follows: ST, KK, BWM and TR designed the research. MV, DY, ST and RP reviewed the literature and extracted data. MV conducted the statistical analyses and wrote the manuscript. All authors contributed to the revisions of the manuscript and read and approved the final version. None of the authors had any personal or financial conflict of interest.

\section{References}

1. Hales CN, Barker DJ, Clark PM, Cox LJ, Fall C, et al. (1991) Fetal and infant growth and impaired glucose tolerance at age 64. BMJ 303: 1019-1022.

2. Barker DJP (1998) Mothers, babies and health in later life (2ndedn) Edinburgh Churchill Livingstone.

3. Whincup PH, Kaye SJ, Owen CG, Huxley R, Cook DG, et al. (2008) Birth weight and risk of type 2 diabetes: a systematic review. JAMA 300: 2886-2897.

4. Chen JH, Martin-Gronert MS, Tarry-Adkins J, Ozanne SE (2009) Maternal protein restriction affects postnatal growth and the expression of key proteins involved in lifespan regulation in mice. PLoS One 4: e4950.

5. Atinmo T, Baldijão C, Pond WG, Barnes RH (1976) Maternal protein malnutrition during gestation alone and its effects on plasma insulin levels of the pregnant pig, its fetuses and the developing offspring. J Nutr 106: 1647-1653.

6. Berney DM, Desai M, Palmer DJ, Greenwald S, Brown A, et al. (1997) The effects of maternal protein deprivation on the fetal rat pancreas: major structura changes and their recuperation. J Pathol 183: 109-115.

7. Bertin E, Gangnerau MN, Bailbé D, Portha B (1999) Glucose metabolism and beta-cell mass in adult offspring of rats protein and/or energy restricted during the last week of pregnancy. Am J Physiol 277: E11-17.

8. Bertin E, Gangnerau MN, Bellon G, Bailbé D, Arbelot De Vacqueur A, et al. (2002) Development of beta-cell mass in fetuses of rats deprived of protein and/or energy in last trimester of pregnancy. Am J Physiol Regul Integr Comp Physiol 283: R623-630.

9. Burdge GC, Lillycrop KA, Jackson AA, Gluckman PD, Hanson MA (2008) The nature of the growth pattern and of the metabolic response to fasting in the rat are dependent upon the dietary protein and folic acid intakes of their pregnant dams and post-weaning fat consumption. Br J Nutr 99: 540-549.

10. Dahri S, Snoeck A, Reusens-Billen B, Remacle C, Hoet JJ (1991) Islet function in offspring of mothers on low-protein diet during gestation. Diabetes 40: 115120.

11. Dahri S, Reusens B, Remacle C, Hoet JJ (1995) Nutritional influences on pancreatic development and potential links with non-insulin-dependent diabetes. Proc Nutr Soc 54: 345-356.

12. Desai M, Byrne CD, Meeran K, Martenz ND, Bloom SR, et al. (1997) Regulation of hepatic enzymes and insulin levels in offspring of rat dams fed a reducedprotein diet. Am J Physiol 273: G899-904.

13. Dumortier O, Blondeau B, Duvillié B, Reusens B, Bréant B, et al. (2007) Different mechanisms operating during different critical time-windows reduce rat fetal beta cell mass due to a maternal low-protein or low-energy diet. Diabetologia 50: 2495-2503.

14. Fernandez-Twinn DS, Ozanne SE, Ekizoglou S, Doherty C, James L, et al. (2003) The maternal endocrine environment in the low-protein model of intrauterine growth restriction. Br J Nutr 90: 815-822.

15. Fernandez-Twinn DS, Wayman A, Ekizoglou S, Martin MS, Hales CN, et al. (2005) Maternal protein restriction leads to hyperinsulinemia and reduced insulin-signaling protein expression in 21-mo-old female rat offspring. Am J Physiol Regul Integr Comp Physiol 288: R368-373.

16. Gosby AK, Maloney CA, Phuyal JL, Denyer GS, Bryson JM, et al. (2003) Maternal protein restriction increases hepatic glycogen storage in young rats. Pediatr Res 54: 413-418.

17. Gosby AK, Stanton LM, Maloney CA, Thompson M, Briody J, et al. (2009) Postnatal nutrition alters body composition in adult offspring exposed to maternal protein restriction. Br J Nutr 101: 1878-1884. 
Citation: Veenendaal MVE, Thangaratinam S, Yates D, Painter RC, de Rooij SR, et al. (2013) Is the Fetal Origins Hypothesis of Diabetes Supported by Animal Research? A Systematic Review and Meta-Analysis of the Evidence. J Diabetes Metab 4: 307. doi:10.4172/2155-6156.1000307

18. Holness MJ (1996) Impact of early growth retardation on glucoregulatory control and insulin action in mature rats. Am J Physiol 270: E946-954.

19. Latorraca MQ, Carneiro EM, Boschero AC, Mello MA (1998) Protein deficiency during pregnancy and lactation impairs glucose-induced insulin secretion but increases the sensitivity to insulin in weaned rats. Br J Nutr 80: 291-297.

20. Martin-Gronert MS, Tarry-Adkins JL, Cripps RL, Chen JH, Ozanne SE (2008) Maternal protein restriction leads to early life alterations in the expression of key molecules involved in the aging process in rat offspring. Am J Physiol Regul Integr Comp Physiol 294: R494-500.

21. Park HK, Jin CJ, Cho YM, Park DJ, Shin CS, et al. (2004) Changes of mitochondrial DNA content in the male offspring of protein-malnourished rats. Ann N Y Acad Sci 1011: 205-216.

22. Petrik J, Reusens B, Arany E, Remacle C, Coelho C, et al. (1999) A low protein diet alters the balance of islet cell replication and apoptosis in the fetal and neonatal rat and is associated with a reduced pancreatic expression of insulinlike growth factor-II. Endocrinology 140: 4861-4873.

23. Petry CJ, Ozanne SE, Wang CL, Hales CN (2000) Effects of early protein restriction and adult obesity on rat pancreatic hormone content and glucose tolerance. Horm Metab Res 32: 233-239.

24. Petry CJ, Dorling MW, Pawlak DB, Ozanne SE, Hales CN (2001) Diabetes in old male offspring of rat dams fed a reduced protein diet. Int J Exp Diabetes Res 2: 139-143.

25. Shepherd PR, Crowther NJ, Desai M, Hales CN, Ozanne SE (1997) Altered adipocyte properties in the offspring of protein malnourished rats. $\mathrm{Br} \mathrm{J}$ Nutr 78: $121-129$

26. Sugden MC, Holness MJ (2002) Gender-specific programming of insulin secretion and action. J Endocrinol 175: 757-767.

27. Wilson MR, Hughes SJ (1997) The effect of maternal protein deficiency during pregnancy and lactation on glucose tolerance and pancreatic islet function in adult rat offspring. J Endocrinol 154: 177-185.

28. Zambrano E, Martínez-Samayoa PM, Bautista CJ, Deás M, Guillén L, et al. (2005) Sex differences in transgenerational alterations of growth and metabolism in progeny (F2) of female offspring (F1) of rats fed a low protein diet during pregnancy and lactation. J Physiol 566: 225-236.

29. Zambrano E, Bautista CJ, Deas M, Martinez-Samayoa PM, GonzalezZamorano M, et al. (2006) A low maternal protein diet during pregnancy and lactation has sex- and window of exposure-specific effects on offspring growth and food intake, glucose metabolism and serum leptin in the rat. J Physiol 571: 221-230.

30. Kind KL, Clifton PM, Grant PA, Owens PC, Sohlstrom A, et al. (2003) Effect of maternal feed restriction during pregnancy on glucose tolerance in the adult guinea pig. Am J Physiol Regul Integr Comp Physiol 284: R140-152.

31. Jimenez-Chillaron JC, Hernandez-Valencia M, Reamer C, Fisher S, Joszi A et al. (2005) Beta-cell secretory dysfunction in the pathogenesis of low birth weight-associated diabetes: a murine model. Diabetes 54: 702-711.

32. Oge A, Isganaitis E, Jimenez-Chillaron J, Reamer C, Faucette R, et al. (2007) In utero undernutrition reduces diabetes incidence in non-obese diabetic mice. Diabetologia 50: 1099-1108.

33. Ford SP, Hess BW, Schwope MM, Nijland MJ, Gilbert JS, et al. (2007) Materna undernutrition during early to mid-gestation in the ewe results in altered growth, adiposity, and glucose tolerance in male offspring. J Anim Sci 85: 1285-1294.

34. Gardner DS, Tingey K, Van Bon BW, Ozanne SE, Wilson V, et al. (2005) Programming of glucose-insulin metabolism in adult sheep after maternal undernutrition. Am J Physiol Regul Integr Comp Physiol 289: R947-954.

35. Husted SM, Nielsen MO, Tygesen MP, Kiani A, Blache D, et al. (2007) Programming of intermediate metabolism in young lambs affected by late gestational maternal undernourishment. Am J Physiol Endocrinol Metab 293 E548-557.

36. Todd SE, Oliver MH, Jaquiery AL, Bloomfield FH, Harding JE (2009) Periconceptional undernutrition of ewes impairs glucose tolerance in their adult offspring. Pediatr Res 65: 409-413.

37. Smith NA, McAuliffe FM, Quinn K, Lonergan P, Evans AC (2010) The negative effects of a short period of maternal undernutrition at conception on the glucoseinsulin system of offspring in sheep. Anim Reprod Sci 121: 94-100.

38. Alvarez C, Martín MA, Goya L, Bertin E, Portha B, et al. (1997) Contrasted impact of maternal rat food restriction on the fetal endocrine pancreas. Endocrinology 138: 2267-2273.
39. Blondeau B, Garofano A Czernichow P Bréant B (1999)Age-dependent inability of the endocrine pancreas to adapt to pregnancy: a long-term consequence of perinatal malnutrition in the rat. Endocrinology 140: 4208-4213.

40. Blondeau B, Lesage J, Czernichow P, Dupouy JP, Bréant B (2001) Glucocorticoids impair fetal beta-cell development in rats. Am J Physio Endocrinol Metab 281: E592-599.

41. Desai M, Babu J, Ross MG (2007) Programmed metabolic syndrome: prenatal undernutrition and postweaning overnutrition. Am J Physiol Regul Integr Comp Physiol 293: R2306-2314.

42. Garofano A, Czernichow $P$, Bréant $B$ (1997) In utero undernutrition impairs rat beta-cell development. Diabetologia 40: 1231-1234.

43. Garofano A, Czernichow P, Bréant B (1998) Beta-cell mass and proliferation following late fetal and early postnatal malnutrition in the rat. Diabetologia 41 : 1114-1120.

44. Garofano A, Czernichow P, Bréant B (1999) Effect of ageing on beta-cell mass and function in rats malnourished during the perinatal period. Diabetologia 42 711-718.

45. Gavete ML, Martín MA, Alvarez C, Escrivá F (2005) Maternal food restriction enhances insulin-induced GLUT-4 translocation and insulin signaling pathway in skeletal muscle from suckling rats. Endocrinology 146: 3368-3378.

46. Holemans K, Van BR, Verhaeghe J, Meurrens K, Van Assche FA (1997) Maternal semistarvation and streptozotocin-diabetes in rats have different effects on the in vivo glucose uptake by peripheral tissues in their female adult offspring. J Nutr 127: 1371-1376.

47. Holemans K, Gerber R, Meurrens K, De Clerck F, Poston L, et al. (1999) Maternal food restriction in the second half of pregnancy affects vascular function but not blood pressure of rat female offspring. Br J Nutr 81: 73-79.

48. Ikenasio-Thorpe BA, Breier BH, Vickers MH, Fraser M (2007) Prenatal influences on susceptibility to diet-induced obesity are mediated by altered neuroendocrine gene expression. J Endocrinol 193: 31-37.

49. Martín MA, Alvarez C, Goya L, Portha B, Pascual-Leone AM (1997) Insulin secretion in adult rats that had experienced different underfeeding patterns during their development. Am J Physiol 272: E634-640.

50. Wang X, Liang L, Du L (2007) The effects of intrauterine undernutrition on pancreas ghrelin and insulin expression in neonate rats. J Endocrinol 194: 121 129

51. Holemans K, Verhaeghe J, Dequeker J, Van Assche FA (1996) Insulin sensitivity in adult female rats subjected to malnutrition during the perinatal period. J Soc Gynecol Investig 3: 71-77.

52. Hernandez-Valencia M, Patti ME (2006) A thin phenotype is protective for impaired glucose tolerance and related to low birth weight in mice. Arch Med Res 37: 813-817.

53. Luther J, Aitken R, Milne J, Matsuzaki M, Reynolds L, et al. (2007) Materna and fetal growth, body composition, endocrinology, and metabolic status in undernourished adolescent sheep. Biol Reprod 77: 343-350.

54. de Leeuw R, de Vries IJ (1976) Hypoglycemia in small-for-dates newborn infants. Pediatrics 58: 18-22.

55. Bebarta V, Luyten D, Heard K (2003) Emergency medicine animal research: does use of randomization and blinding affect the results? Acad Emerg Med 10: 684-687.

56. Mahajan SD, Singh S, Shah P, Gupta N, Kochupillai N (2004) Effect of materna malnutrition and anemia on the endocrine regulation of fetal growth. Endocr Res 30: 189-203.

57. Stanner SA, Bulmer K, Andrès C, Lantseva OE, Borodina V, et al. (1997) Does malnutrition in utero determine diabetes and coronary heart disease in adulthood? Results from the Leningrad siege study, a cross sectional study. BMJ 315: 1342-1348.

58. de Rooij SR, Painter RC, Roseboom TJ, Phillips DI, Osmond C, et al. (2006) Glucose tolerance at age 58 and the decline of glucose tolerance in comparison with age 50 in people prenatally exposed to the Dutch famine. Diabetologia 49 : 637-643.

59. Ravelli AC, van der Meulen JH, Michels RP, Osmond C, Barker DJ, et al. (1998) Glucose tolerance in adults after prenatal exposure to famine. Lancet 351: 173 177. 
Citation: Veenendaal MVE, Thangaratinam S, Yates D, Painter RC, de Rooij SR, et al. (2013) Is the Fetal Origins Hypothesis of Diabetes Supported by Animal Research? A Systematic Review and Meta-Analysis of the Evidence. J Diabetes Metab 4: 307. doi:10.4172/2155-6156.1000307

Page 8 of 8

60. de Rooij SR, Painter RC, Phillips DI, Osmond C, Michels RP, et al. (2006) Impaired insulin secretion after prenatal exposure to the Dutch famine. Diabetes Care 29: 1897-1901.
61. Li Y, He Y, Qi L, Jaddoe VW, Feskens EJ, et al. (2010) Exposure to the Chinese famine in early life and the risk of hyperglycemia and type 2 diabetes in adulthood. Diabetes 59: 2400-2406. 